\title{
IS THE MESSIAH ANNOUNCED IN MALACHI 3:1?
}

\author{
Andrew S. Malone
}

\begin{abstract}
Summary
Malachi 3:1 is often touted as a key messianic text: YHWH supposedly announces the sending of the Messiah and a preceding messenger, a pattern confidently identified by Jesus himself. Such an interpretation continues to be published by evangelicals in both popular and scholarly works. Closer inspection, however, suggests that this conclusion is not supported by exegesis nor by all conservative interpreters. This can result in uncertainty for evangelical readers and even in the bringing of disrepute upon evangelical conclusions and methodology. This study of a familiar problem surveys the interpretative options of the identities involved, evaluates what can be said with confidence, and demonstrates a defensible christological way forward.
\end{abstract}

\section{Introduction}

Christians have long sought to demonstrate the christological value of the Old Testament. Malachi 3:1 is one passage regularly quarried for its New Testament significance. It is cited in the New Testament, even by Jesus, and it refers to otherwise undefined angels/messengers of YHWH. Because of the New Testament's application of the verse to the coming of the Messiah, it is reasonable to seek here a reference to the Messiah. Because of the lack of definition of the various characters in the verse, there is little to impede a messianic identification. Malachi 3:1 is thus among the first of any Old Testament texts surveyed in popular Christian messianic studies, ancient and modern. ${ }^{1}$ Even more

1 Modern popular studies, e.g. Robert L. Reymond, Jesus, Divine Messiah (Fearn: Mentor, 2003): 149-58; Walter C. Kaiser Jr, The Messiah in the Old Testament (Grand 
sober analyses of the verse in its Old Testament context endorse the traditional interpretation that here we see the prediction of the coming of John the Baptist and Jesus, and that 'the messenger/prophet announces the coming of the messiah.' ${ }^{2}$

Why another survey of this topic, when the interpretative issues surrounding the verse itself, its immediate pericope (2:17-3:5), and ever-wider spheres of context are well documented in the commentaries? Four answers may be given. First, despite the trend towards more and longer commentaries, few really offer the space to document thoroughly the interpretative options. ${ }^{3}$ Second, dogmatic pressures often lead scholars and readers to take shortcuts, either consciously or unconsciously. Third, when it comes to a passage so clearly adopted and interpreted in the New Testament, it can be difficult to disengage that later influence in order to determine what Malachi and his audience(s) first understood. Yet this is an essential step, one often overlooked, before addressing the increasingly popular investigations of how the Old and New Testaments interact. Fourth, while conservative interpreters are agreed that the verse has messianic value, there is simply not yet consensus on how to identify him in this famous part of Scripture.

Despite all the additional comments that could be made concerning the wider pericope, this study focuses only on the identities of the figures involved in Malachi 3:1. Any messianic relevance depends upon what is said about whom. We will survey the titles used to label the various characters involved, and what can be said about them individually and in combination with each other. We will observe how Christian interpreters have employed the verse in laudable attempts to have 'all the Scriptures' attest the Messiah (Luke 24:25). The study concludes that the passage is indeed messianic, although within particular interpretative limits. It highlights and evaluates the assumptions

Rapids: Zondervan, 1995): 227-29; J. Barton Payne, Encyclopedia of Biblical Prophecy (London: Hodder \& Stoughton, 1973): 473; Herbert Lockyer, All the Messianic Prophecies of the Bible (Grand Rapids: Zondervan, 1973): 65.

2 Daniel I. Block, 'My Servant David: Ancient Israel's Vision of the Messiah', in Israel's Messiah in the Bible and the Dead Sea Scrolls, ed. Richard S. Hess and M. Daniel Carroll R. (Grand Rapids: Baker Academic, 2003): 17-56, esp. 32; cf. O. Palmer Robertson, The Christ of the Prophets (Phillipsburg: P\&R, 2004): 401-02.

3 Except arguably for the detailed work of Andrew E. Hill, Malachi (AB 25D; New York: Doubleday, 1998): here 259-91. 
often made, and urges evangelical interpreters not to let good doctrine supplant careful exegesis.

\section{Clarifying the Characters}

Who are the figures described in the verse? Which one, if any, is the Messiah? As we consider these characters, we do well to tread cautiously. The warnings that 'A solution to these issues is not simple' and that 'To be dogmatic about Mal 3:1 would be unwise' are not excuses of authors trying merely to placate diverse opinions amongst their readers. ${ }^{4}$

The verse uses four different labels or titles, allowing the reader to identify up to four distinct characters. ${ }^{5}$ These can be readily recognised and enumerated:

1. There is the first-person speaker, ' $I$ '.

2. This speaker promises to send 'my messenger' (Heb. mal'aki).

3. Consequently, 'the Lord' (ha'adon, not YHWH 'the LORD') will come to his temple.

4. The coming is also announced of 'the messenger of the covenant' (mal'ak habberit).

A fifth title in the final clause, 'YHWH Sabaoth', is regularly accepted as the explicit identity of the first-person speaker.

Distinguishing these labels is not in doubt. What is in dispute is how, if at all, any of them might overlap with another. Some scholars are content that the speaker, 'I ... YHWH Sabaoth', speaks of three separate characters. ${ }^{6}$ This already recognises that the 'I' overlaps with one of the other titles. And many would find even fewer characters. That is, at least two of the remaining labels ('my messenger', 'the Lord', and 'the messenger of the covenant') are alternate descriptions

4 Respectively, Julia M. O’Brien, Nahum, Habakkuk, Zephaniah, Haggai, Zechariah, Malachi (AOTC; Nashville: Abingdon, 2004): 305; David L. Petersen, Late Israelite Prophecy (SBLMS 23; Missoula: Scholars, 1977): 42.

5 Rightly Richard A. Taylor and E. Ray Clendenen, Haggai, Malachi (NAC 21A; Nashville: Broadman \& Holman, 2004): 384. All renderings of biblical texts are my own. I recognise that that the word mal'ak can mean 'angel' as much as '(human) messenger' but, for reasons explained later, I avoid the former translation which is derivative and potentially misleading.

6 E.g. Hill, Malachi: 286-89; Joyce G. Baldwin, Haggai, Zechariah and Malachi (TOTC; Leicester: IVP, 1972): 242-43; Bruce V. Malchow, 'The Messenger of the Covenant in Mal 3:1', JBL 103 (1984): 252-55, esp. 253. 
applied to one individual. Even some of those listed in the preceding footnote are unwilling to rule this out. And so we turn to consider some of the plausible combinations.

\section{Combinations of Titles}

It is at this point that scholars' presuppositions start to colour their evaluations, in turn affecting how they read the entire verse. It is incumbent upon us to consider carefully the evidence that exists for identifying the characters involved.

In this section, we consider why particular titles are sometimes paired: on what grounds two of the labels are deemed to apply to the same individual. Having done this we will be better able to investigate, in the next section, the 'who's who' of the verse as a whole.

\section{1 ' $I$ ' = the LORD}

We have already noted that this identification is not contentious. Regardless of any compositional history, ${ }^{7}$ or quibbles over punctuation, ${ }^{8}$ the final form of the pericope is clear. The speaker of the whole is YHWH Sabaoth $(3: 1,5)$, describing the preparation of 'the way before me' (3:1) such that 'I will come near to you' (3:5). It is only later that we need question to whom the label YHWH might refer.

\subsection{The Lord $=$ the LORD}

After YHWH, the title 'the Lord' is the simplest to determine. The indefinite 'adon can apply as readily to humans as to deities. ${ }^{9}$ But the definite ha'adon more clearly requires a divine referent. It is agreed by a variety of commentators that 'elsewhere in the OT/HB, 'àdôn with the definite article is always paired with YHWH indicating that this is whom Malachi has in mind as well (cf. Exod 23:17; 34:23; Isa 1:24; $3: 1 ; 10: 16,33 ; 19: 4)^{\prime} .{ }^{10}$

7 E.g. David L. Petersen, Zechariah 9-14 and Malachi (OTL; Louisville: Westminster/John Knox, 1995): 207-12.

8 E.g. Douglas Stuart, 'Malachi' in The Minor Prophets, ed. Thomas E. McComiskey (Grand Rapids: Baker, 1998), 3:1245-1396, at 1352.

9 Gordon H. Johnston, 'אָדרוך (123)', NIDOTTE 1:256-61, at 257, finds a ratio of 10:1 in favour of human: divine referents.

10 Hill, Malachi: 268 (cf. 289); Walter C. Kaiser Jr, Micah-Malachi (Dallas: Word, 1992): 473; also Ernst W. Hengstenberg, Christology of the Old Testament (18531857; reprint, 2 vols.; Mac Dill: MacDonald, 1972), 2:1206; Eugene H. Merrill, 
This also accords well with the whole pericope. Malachi's audience has complained, 'Where is the God of justice (mishpat)?' (2:17). The following verses repeat YHWH's answer: 'See, I am sending my messenger and he will prepare the way before me' (3:1); and 'I will come near to you for judgement (mishpat)' (3:5). ${ }^{11}$ The identification of 'the Lord' as 'the LORD' thus fits perfectly:

- YHWH describes ha'adon as 'coming'.

- This 'Lord' comes 'to his temple' - a phrase hard to attribute to someone other than YHWH. ${ }^{12}$

- This 'Lord' is further described as the one 'whom you are seeking'. It would seem an obvious reference to the 'search' of 2:17.

Although occasional dissenters can be found 'there is almost universal agreement among both Jewish and Christian interpreters that the reference to the Lord (ha' 'âdôn) is to Yahweh himself.'13

\subsection{The Messenger of the Covenant $=$ the Lord}

The next most agreed overlap is of the third and fourth figures. Such an equation is important, because the title 'the messenger of the covenant' is unique, and is otherwise open to alternative identifications (see below).

That this 'messenger' and 'the Lord' describe the same individual is easily demonstrated. Both are accompanied by similar relative clauses ('whom you seek', 'whom you delight in') and both are described as 'coming' (using the same Hebrew verb). The parallelism, of clauses and thus of identities, is further encouraged if a wider chiastic structure is recognised. ${ }^{14}$

Haggai, Zechariah, Malachi (Chicago: Moody, 1994): 430, 434 n. 17. These and others also cite the divine title 'the Lord ('adon) of all the earth' (Zech. 4:14; 6:5), though the equation with YHWH is better made in examples earlier in the OT (Josh. 3:11-13; Ps. 97:5; Mic. 4:13).

11 Cf. Pamela J. Scalise, 'To Fear or Not to Fear: Questions of Reward and Punishment in Malachi 2:17-4:3', RevExp 84 (1987): 409-18, esp. 410.

12 'The "Lord" comes to his temple. Who except YHwh would possess a temple in Israel?' (Adam S. van der Woude, 'Der Engel des Bundes: Bemerkungen zu Maleachi 3,1c und seinem Kontext' in Die Botschaft und die Boten, ed. Jörg Jeremias and Lothar Perlitt [Neukirchen-Vluyn: Neukirchener, 1981]: 289-300, at 295, my translation, italics original).

13 Hill, Malachi: 287; also van der Woude, 'Der Engel': 294 n. 24; Malchow, 'Messenger': 253.

14 Especially clear in Taylor and Clendenen, Haggai, Malachi: 384-85; Robertson, Christ of the Prophets: 401; Pieter A. Verhoef, The Books of Haggai and Malachi (NICOT; Grand Rapids: Eerdmans, 1987): 288-89. 


\subsection{Other matters}

That the two occurrences of 'messenger' (mal'ak) should be equated makes some linguistic sense. A not-insignificant minority promotes this. ${ }^{15}$ However, the term is sufficiently broad that we cannot demand that every occurrence connotes the same individual or even the same kind of person. ${ }^{16}$

The question of identities can also be influenced by one's understanding of the temporal sequence outlined here. Scholars prefer that the opening interjection and participle indicate a pending action (' $\mathrm{I}$ am about to send', REB; cf. NASB, JB) rather than a present reality ('I am sending', NEB, NRSV, NKJV, NLT, ESV). ${ }^{17}$ There is less consensus over the delay between the first messenger and the coming Lord. Is the Hebrew (pit'om) quantitative ('soon') or qualitative ('suddenly')? Most lean towards the latter. ${ }^{18}$ Whether these give the impression of an immediate response to the Israelite community, or predict only the coming of the Messiah at a later time, is coloured by one's presuppositions.

Perhaps of significance is that this latter adverb occurs 'almost exclusively of a disastrous nature ... to describe the suddenness of Yahweh's judgment'. ${ }^{19}$ While not untrue of Christ's coming, this negative flavour of Malachi's oracle - abundantly clear in the following verses - is not always noted in messianic interpretations.

15 E.g. Merrill, Haggai, Zechariah, Malachi: 429; Petersen, Zechariah 9-14 and Malachi: 211; Scalise, 'Questions': 410-11; William J. Dumbrell, 'Malachi and the Ezra-Nehemiah Reforms', RTR 35 (1976): 42-52, esp. 48; Steven L. McKenzie and Howard N. Wallace, 'Covenant Themes in Malachi', CBQ 45 (1983): 549-63, esp. 553; R. T. France, Jesus and the Old Testament (London: Tyndale, 1971): 91-92.

16 Stuart, 'Malachi', 3:1351. Stuart argues that the application of mal'ak to the (ideal) priest in 2:7 demonstrates the flexibility of the title. However, the 'covenant' of 3:1 is not infrequently considered to be the Levitical covenant, with the actions of the coming YHWH (or his mal'ak) in 3:2-4 the refining of the temple cultus; e.g. John B. Taylor, 'And He Shall Purify: an Exposition of Malachi Chapters Two and Three', Anvil 15 (1998): 6-12; McKenzie and Wallace, 'Covenant Themes': 554-55; Merrill, Haggai, Zechariah, Malachi: 433-35.

17 Especially Beth Glazier-McDonald, Malachi (SBLDS 98; Atlanta: Scholars, 1987): 135; Verhoef, Haggai and Malachi: 287; Hill, Malachi: 265; GKC §116p; IBHS $\$ 40.2 .1 \mathrm{~b}$. Note also the less-precise future translation ('I will send', AV, NJB, NIV). The alternation of tenses between various revisions of Bible versions attests the difficulty here.

18 E.g. Verhoef, Haggai and Malachi: 288; Hill, Malachi: 267, who also notes the emphatic position of this adverb.

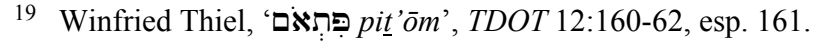


A final point which will assist in our identification of the characters involved is that this passage is regularly considered to be an intentional echo of the language of Exodus 23:20-23. Alert commentators note that there are a number of differences between these passages. ${ }^{20}$ Of particular relevance is that christocentric interpretations of Exodus hastily conclude that the language there of 'See, I am sending a messenger before you ... my name is in him' confirms an allusion to the Father sending the Son..$^{21}$

Armed with these observations and the likely pairings of titles, we can now consider what further identifications can be made of the various characters in Malachi's famous verse.

\section{Combinations and Identifications of Characters}

We have seen that few scholars accept four distinct characters, and that there are good grounds for letting some of the labels overlap. A logical approach would exhaustively check all fourteen possible combinations in which the four labels might be assigned to one or two or three characters. However, having considered which combinations of labels are already likely, it is easier for us simply to survey each of the labels and its likely identification(s). This will demonstrate the likely number of individuals involved. It also affords orderly scrutiny of each of the titles, to determine which (if any) denotes the Messiah. We can work through the four labels in the same order introduced in $\S 2$.

\section{1 ' $I$ '}

In a bid to find the Messiah here, some suggest that the speaker is Christ himself. But there is no demonstrable reason for doing this as the Old Testament text stands, and the suggestion has been widely abandoned. Indeed, the weakness of earlier attempts to do this can be readily exemplified.

20 E.g. McKenzie and Wallace, 'Covenant Themes': 553-54.

21 Cf. Walter C. Kaiser Jr, Toward an Old Testament Theology (Grand Rapids: Zondervan, 1978): 120-21; John L. Mackay, Exodus (Fearn: Mentor, 2001): 407-9; J. Alec Motyer, The Message of Exodus (BST; Leicester: IVP, 2005): 50-51. This conclusion also relies on the observation that the messenger/angel there speaks and judges for God. Mal. 3:1 may also contain an allusion to Isa. 40:3-5, but this makes no additional impact on interpretation. 
Calvin insists that the speaker must be the Trinitarian Son, who here predicts the coming of John the Baptist prior to his own advent. (The later labels, 'Lord' and 'messenger of the covenant', are also the Son's self-descriptions.) Yet Calvin cannot accept the title 'YHWH Sabaoth' for the Son, and thus attributes the last declaration ('See, he is coming') to the Father. ${ }^{22}$ There is, of course, no textual warrant for making this arbitrary division. Moreover, it works against the usual identification of the speaker as YHWH Sabaoth (\$3.1), and breaches any chiastic structure within the speech (n. 14).

Luther appears to retain these various parallelisms, attributing the speech to Christ. ${ }^{23}$ Although consistent with his insistence that any speech of YHWH can be attributed 'to our Lord Jesus Christ, God's Son', ${ }^{24}$ Luther has breached another of his interpretative rules. $\mathrm{He}$ regularly supposes that one cannot refer to oneself in the third person..$^{25}$ His methods prove inconsistent if he demands that here the Son speaks of his own coming.

(We will shortly revisit this issue, and rely on the notion that one can speak of oneself in the third person. Luther is incorrect as well as inconsistent. Although his supposition is echoed in a surprising number of systematic theologies and commentaries, ${ }^{26}$ it is patently false. In the Bible alone we find Lamech referring to the 'wives of Lamech' [Gen. 4:23], and Christ praying 'glorify your Son ... whom you have sent, Jesus Christ' [John 17:1-3]. Traditional Christology turns precisely on 'the Son of Man' being a third-person self-reference. Such biblical examples can be easily multiplied. Any attempt, such as Luther's or Calvin's, to have the Son speaking here of his own coming relies precisely upon this possibility.)

22 John Calvin, Commentaries on the Twelve Minor Prophets. Mal. 3:1 (1559).

23 Martin Luther, Lectures on Malachi (1526/1554), LW 18:408. We presume that this also attributes the title 'YHWH Sabaoth' to the speaking Messiah, though Luther is silent. The alternative is that, like Calvin, Luther arbitrarily assigns different parts of the verse to different speakers, a division he never explicates.

24 Martin Luther, On the Last Words of David (1543), LW 15:336.

25 Luther, e.g. Last Words, LW 15:335-36; cf. 279-80, 326-32; The Three Symbols or Creeds of the Christian Faith (1538), LW 34:226. Heinrich Bornkamm confirms 'the approach Luther used countless times ... [F] or it was certainly one of his noblest methods of proving Christ as second person next to the Father on the basis of the repetition of God's name' (Luther and the Old Testament [Philadelphia: Fortress, 1969; tr. from German, 1948]: 103, 205).

26 E.g. Motyer, Exodus: 51: 'Yahweh announces the coming of the Angel as though speaking of someone else.' 
We have thus seen that there are no grounds for distinguishing between Father and Son from the text alone, though we have not ruled out that 'YHWH Sabaoth' may refer to the Son either as an individual or as part of the Trinity. Verhoef is correct that further over-specification of the speaker's identity 'is more a dogmatic than an exegetical conclusion'. ${ }^{27}$ We have also discovered that the speaker need not be distinguished from the characters he proceeds to discuss.

\section{2 'My messenger'}

Except for those who would equate the two messengers (n. 15), this term presents little difficulty. In light of the parallel discussion in 4:5-6 ('See, I am sending to you Elijah the prophet'; MT 3:23-24) and the ways these Malachi verses are expounded in the New Testament, consensus is near universal that the term refers to a human, likely prophetic, messenger. Whether there is in view one particular prophet or a number filling that office, and how the label mal'aki might refer to the book's namesake is beyond our current concern.

\section{3 'The Lord'}

Having demonstrated the close and accepted link between the third and fourth titles (§3.3), much of what can be said here for 'the Lord' will also apply to 'the messenger of the covenant'. It is at this point that evangelical desires to harmonise Old and New Testaments are particularly prone to moving too quickly beyond the text.

The traditional christological reading of this verse is that YHWH promises to send his (human) messenger before the coming of the Lord. That John the Baptist precedes the coming of the incarnate Son, and that this verse is invoked in the New Testament to describe such, is what supposedly secures the messianic interpretation. Commentators on Malachi enthusiastically proclaim this: the verse 'is overtly messianic' and depicts God 'sending his messianic representative'. ${ }^{28}$ Yet we have seen that there is no basis for the common, necessary presumption

27 Verhoef, Haggai and Malachi: 287.

28 Respectively, Stuart, 'Malachi', 3:1351-52; Robertson, Christ of the Prophets: 401. Also Kaiser, Micah-Malachi: 473; Block, 'My Servant David': 32. 
that "the one speaking ("the LORD of hosts") distinguishes himself from "the Lord whom you seek," suggesting two separate persons' ${ }^{29}$

The alternative view, argued above, is that 'the Lord' is how 'the LORD' refers to himself in this passage. Of course, it need not be a self-reference; this is how one would speak of a third party, such as the Messiah. Yet to do so would stumble over the other self-references here: 'my messenger ... before me ... I will come near'.

These distinctions and arguments might appear subtle. But we must be alert to them, such that we are not drawn by - or guilty of - incomeplete arguments. For example, Kaiser rightly recognises that the first messenger clears the way 'before the LORD'; notes that the coming 'Lord' addresses the complaint of 2:17; and articulates the connection between the articular ha'adon and $Y H W H .{ }^{30}$ Yet having equated the two, he simply assumes (with a nod to the disputed 'adonay of Psalm 110:1) that there is also a distinction..$^{31}$

Scholars like Kaiser are, of course, keen to conform to the authority of the New Testament, either implicitly or explicitly. But we should also be careful to note precisely what the New Testament does with this verse. The three clear citations (Matt. 11:10= Mark 1:2= Luke 7:27) all incorporate the related passage from Exodus 23:20 (Matthew being identical to LXX Exodus, the other two merely omitting a redundant pronoun), before giving a non-LXX translation of Malachi 3:1. It is the Gospels that introduce a distinction between the speaker who sends and the 'you' whose way will be prepared. The first distinct 'you' has come from Exodus, where it has no messianic referent at all. The second distinct 'you' is either influenced by the Exodus passage (which continues in this second-person vein) or represents an interpretation of Malachi in the light of New Testament events. It is significant to note that New Testament commentators regularly refuse to see messianic intention in Malachi's original words. ${ }^{32}$ As we shall see shortly, there is

29 Wayne A. Grudem, Systematic Theology (Downers Grove: IVP, 1994): 228; cf. John S. Feinberg, No One Like Him (Wheaton: Crossway, 2001): 454. This argument seems to presuppose the impossibility of third-person self-references.

30 Kaiser, Micah-Malachi: 472-73. The last point is expressed with almost identical wording and examples to Hill's argument at $\mathrm{n} .10$ above.

31 Kaiser's argument is reproduced almost verbatim in his Messiah: 228; cf. Hengstenberg, Christology, 2:1279; Reymond, Jesus, Divine Messiah: 159, with his claim that 'on the basis of exegesis' such a passage anticipates 'a Messiah who would be divine in nature'.

32 E.g. D. A. Carson, 'Matthew' in Expositor's Bible Commentary, ed. Frank E. Gæbelein (Grand Rapids: Regency, 1984), 8:1-599, esp. 264; Robert H. Gundry, 
a more consistent way to understand this interpretation than to enforce a distinction in Malachi where none appears to be warranted. ${ }^{33}$

\section{4 'The messenger of the covenant'}

The obscurity of this final figure is what affords a range of interpretations; it is a wildcard that can fit a number of predetermined conclusions. What is pertinent here is to consider the methods and conclusions that can be reached, in order to evaluate those which are more or less probable.

We have noted the general disinterest in pairing together the two 'messengers' of this one verse. It is fascinating, then, to see how many hasten to affirm that this 'messenger/angel of the covenant' should be identified with the enigmatic 'Angel of YHWH' whose appearances are concentrated in the opening books of the Old Testament. ${ }^{34}$

Such an approach is obviously inconsistent. In part it does condone reliance on a word's repetition, despite reluctance to identify mal'ak and mal'ak within this single verse in Malachi. In part it is a dogmatic, arbitrary identification, for the first of Malachi's messengers/angels

Matthew (2nd edn; Grand Rapids: Eerdmans, 1994): 207-8; Morna D. Hooker, The Gospel According to Mark (BNTC; London: A\&C Black, 1991): 34-36; R. T. France, The Gospel of Mark (NIGTC; Grand Rapids: Eerdmans, 2002): 63-64, a good introduction to textual matters; I. Howard Marshall, The Gospel of Luke (NIGTC; Grand Rapids: Eerdmans, 1978): 59, 296; Darrell L. Bock, Luke 1-9:50 (BECNT 3A; Grand Rapids: Baker, 1994): 674. That such texts as Mal. 3:1, Exod. 23:20, and Isa. 40:3 may have already been conflated and applied in a generic manner (i.e. with no particular referent in mind), see Robert A. Bascom, 'Preparing the Way - Midrash in the Bible', in Issues in Bible Translation, ed. Philip C. Stein (London: United Bible Societies, 1988): 221-46, e.g. 239.

$33 \mathrm{UBS}^{4}$ also lists a number of possible allusions to Mal. 3:1. Some have no direct impact on our messianic identification. Others, if pressed, might argue in favour of 'the Lord' as YHWH. So Gabriel's annunciation that John's work would prepare Israel for 'the Lord their God' (Luke 1:16-17), or Zechariah's prophecy that his son would be a prophet of 'the Most High' (1:76) - the language of God the Father $(1: 32,35)$.

34 E.g. Verhoef, Haggai and Malachi: 289; Kaiser, Micah-Malachi: 473; James B. DeYoung, 'The Function of Malachi 3.1 in Matthew 11.10', in The Gospels and the Scriptures of Israel, ed. Craig A. Evans and W. Richard Stegner (JSNTSup 104; SSEJC 3; Sheffield: Sheffield Academic, 1994): 66-91, esp. 73; Robert L. Reymond, A New Systematic Theology of the Christian Faith (2nd edn; Nashville: Thomas Nelson, 2002): 208; Motyer, Exodus: 50-51; Ralph L. Smith, Micah-Malachi (WBC 32; Waco: Word, 1984): 328. For a recent survey of 'the Angel of YHWH' as the preincarnate Christ, see James A. Borland, Christ in the Old Testament: Old Testament Appearances of Christ in Human Form (2nd edn; Fearn: Mentor, 1999). It is even claimed that Malachi's verse 'furnishes the key to the whole phenomenon of the Malakh Yahwe' (J. Barton Payne, The Theology of the Older Testament [Grand Rapids: Zondervan, 1962]: 169). 
arguably has better parallels to that earlier Angel than does the second. ${ }^{35}$ In part it is circular, claiming a (messianic) interpretation for Malachi's 'messenger of the covenant' based on a prejudged, christological interpretation of the pentateuchal Angel. And in part it is inefficient, even misleading, in intimating that this earlier Angel (and its relevance to Malachi 3:1) is more widely agreed and determinative than the better attested 'the Lord'.

The inconsistency impacts scholarship in a number of ways. Firstly, it produces disagreement within evangelical circles. How does it appear when leading Old Testament scholars (n. 28) reach conclusions contrary to their New Testament counterparts (n. 32)? What about internal discrepancies among Old Testament authors or among systematic theologians? Surely this does little to commend evangelical methodologies, either to those within or without that confessional stance.

Secondly, the inconsistency can lead the surest exegetes astray. We have seen above the unfounded presumptions of systematicians, and the step missing from Kaiser's otherwise helpful exposition. So too with Stuart's detailed work (within a series overtly subtitled An Exegetical ... Commentary). He encourages the common, messianic identifications: 'The messenger sent as forerunner is John the Baptist, and the Lord, the covenant messenger, is Christ.' 36 The first and second messengers are distinct. Yet his ensuing discussion of verses 2-4 confuses the two. He initially judges the first, 'my messenger', to be the agent of this pending purification. ${ }^{37}$ But, perhaps because he has earlier noted how the Old Testament 'Angel of YHWH' is difficult to distinguish from YHWH himself, Stuart starts speaking of the second messenger as this agent. ${ }^{38}$ Either Stuart has indeed conflated the two messengers, contrary to his earlier exegesis, or he has introduced a theology of

35 E.g. Hill, Malachi: 288. The recognised parallels between Mal. 3:1 and Exod. 23:20-23, where God sends an angel (called mal'aki in 23:23!), are foremost in such an argument.

36 Stuart, 'Malachi', 3:1351; cf. Kaiser, Micah-Malachi: 473.

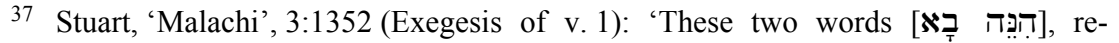
sumptive of the promise of sending "my messenger" at the beginning of the verse, are best taken as the outset of a sentence that continues in verse 2, thus, "He is coming (said Yahweh of the Armies), but who can endure." This clearly identifies the thirdperson referent of vv. 2-4.

38 Stuart, 'Malachi', 3:1353 (Exposition of v. 2): 'With regard to Christology, this verse and those that follow it are important Old Testament precursors of trinitarian theology. The messenger who is sent by Yahweh in 3:1 turns out to be none other than Yahweh himself. How can God both send and be sent?' 
sending for this second 'messenger' which neither he nor the text expounds. If anything, the confusion is caused by his high regard for Scripture - but the result is good doctrine at odds with good exegesis.

Indeed, such confusion may be the lot of all those who carelessly identify 'the messenger of the covenant' with 'the messenger/Angel of YHWH'. The clear parallel with Exodus 23, and any Angel theology there, is with Malachi's first messenger. With the majority seeing a substantial distinction between the first and second messengers, it is inviting trouble to also compare the Angel of YHWH with Malachi's second messenger. ${ }^{39}$

So while myriad interpretations abound of the identity of 'the messenger of the covenant' (and of the 'covenant' itself), the text is not at all forthcoming. The most confident identification we can offer is the parallel with 'the Lord'. Yet the traditional messianic reading often works against this one rare detail that the passage does yield.

\section{A Christological Way Forward}

With so many possible combinations and identifications it might seem improbable to suggest that virtually all of these answers can, to a certain degree, be amalgamated into a unified whole. This is not to confirm all scholars in every conclusion, nor to absolve them of every mistake. Neither is it to claim a hitherto unseen interpretation. Rather, we can evaluate how the above data can and has been put to responsible use.

The combinations of $\S 3$ suggest that we have only two figures involved. YHWH Sabaoth speaks of his pending arrival, preceded by a probably-human messenger. The coming 'LORD' YHWH is further labelled 'the Lord' and also the enigmatic 'messenger of the covenant'. ${ }^{40}$ This preserves what can be said confidently about the two messengers, without the arbitrary and even contradictory notions that

39 Although generally better handled, DeYoung ('Function': 70-73, 89) similarly makes it hard to navigate the supposed parallels between YHWH-Angel in Exodus and YHWH-messenger(s) in Malachi.

40 This interpretation is further endorsed by NT scholars who recognise that the prophetic forerunner, usually identified or labelled as Elijah, 'prefigures not the Messiah but the appearance of God himself' (James R. Edwards, The Gospel according to Mark [PNTC; Grand Rapids: Eerdmans, 2002]: 27-28; cf. Craig S. Keener, A

Commentary on the Gospel of Matthew [Grand Rapids: Eerdmans, 1999]: 338, and those in $\mathrm{n.} 32$ above). 
the 'Angel of YHWH' imports. It retains the sense of the language from Exodus 23, without requiring the two passages to be synonymous (the differences are frequently noted). Most important of all, these identifications are consistent with - even dictated by - the text of Malachi itself.

Moreover, while they may challenge the popular messianic categories, these identifications do not sacrifice the actual messianic value of the verse. Rather, they promote an even higher Christology than the traditional messianic reading often settles for. When Jesus and the evangelists apply the prophecy, it is abundantly clear that Jesus himself is no less than the coming YHWH, 'the Lord (of all the earth)'!41 The christological value lies in equating the Messiah with YHWH and not in trying to distinguish the two. It is in this light that the Gospels can shift the pronoun from 'prepare the way before $m e$ ' to 'prepare your way before you' ${ }^{42}$ It is in the New Testament, rather than the Old, that we determine the Messiah's claim to 'his temple'.

We need not therefore discard Malachi 3:1, though we may need to reclassify it. It should no longer be considered amongst the oftennebulous category of predictive messianic texts - a simplistic mould into which this verse cannot responsibly be squeezed. It is better counted amongst those Old Testament passages which are appropriated by the New Testament, whereby the attributes and activities of YHWH himself are recognised in and ascribed to Jesus.

41 Cf. France, Jesus: 92, 155; Millard J. Erickson, The Word Became Flesh (Grand Rapids: Baker, 1991): 448; John M. Frame, The Doctrine of God (Phillipsburg: P\&R, 2002): 652-54; Larry W. Hurtado, Lord Jesus Christ (Grand Rapids: Eerdmans, 2003): 251; Taylor and Clendenen, Haggai, Malachi: 385-86; Reymond, Jesus, Divine Messiah: 153-54 (despite the indiscretion cited at n. 31).

42 Cf. Donald A. Hagner, Matthew 1-13 (WBC 33A; Dallas: Word, 1993): 305. Mark's version omits the final prepositional phrase. While not finally convincing, note the not unreasonable suggestion that the 'you' here applies to the people of God promoted by Bock, Luke 1-9:50: 672-75. 